\title{
BENDING PROPERTIES OF STEEL SHEET PILES PARTIALLY COVERED BY REINFORCED CONCRETE
}

\author{
By Osamu KIYOMIYA*, Hiroshi YOKOTA** and Takatoshi NOGUCHI***
}

\begin{abstract}
A steel sheet pile in marine environments may have been damaged greatly by corrosion. Reinforced concrete covering is an effective repair technique for such damaged steel sheet piles. The repaired part of the sheet piles can be designed as a composite structure with reinforced concrete and the steel. Its design method and structural details have to be made clear. Loading tests on eight test specimens have been undertaken to investigate their mechanical properties and to verify the design formulae. Through the loading tests, ultimate strength, crack development, and so on depended on the arrangement of shear connectors and concrete cover length.

Keywords : composite beam, loading test, steel sheet pile, repair work
\end{abstract}

\section{INTRODUCTION}

Steel sheet piles have been used rather frequently for port and harbour facilities such as piers and seawalls. Corrosion is feared in steel which is in contact with sea water. Severe corrosion is limited in the zone between high and low water levels. Anti-corrosion methods and repair methods are required to be established. As a repair method for damaged steel sheet piles, reinforced concrete covering technique has been frequently used in port and harbour facilities. The concrete covering will be applied to the part where its sectional stiffness is remarkably decreased. At the covered part, reinforced concrete and the steel sheet pile are mechanically combined by studs. The method on design and installation is summarized in the Manual $^{1)}$. However, sufficient discussion on strength and durability of the concrete covering method has not been made, and many technical problems are remaining. In particular, how to compose the two materials and how to estimate the strength of the composite pile are not made clear. In the present paper, these problems are examined by loading tests and the applicability of the design formulae in the Manual is discussed.

\section{BACKGROUND OF INVESTIGATION}

\section{(1) Corrosion of steel sheet pile}

Steel sheet piles are installed in front of a pier as illustrated in Fig. 1. Steel sheet piles are located between an upper slab and sea mud. According to corrosion investigation ${ }^{2(3)}$, corrosion amount along steel sheet piles which have been used for 14 years is obtained in Fig. 2.

\footnotetext{
* Member of JSCE, Dr. Eng., Chief, Structural Mechanics Laboratory, Port and Harbour Research Institute, Ministry of Transport (Nagase 3 chome 1-1, Yokosuka-shi, Kanagawa)

** Member of JSCE, M. Eng., Deputy head of Yokohama Investigation and Design Office, Ministry of Transport

*** Member of JSCE, Member of Structural Mechanics Laboratory, Port and Harbour Research Institute, Ministry of Transport
} 


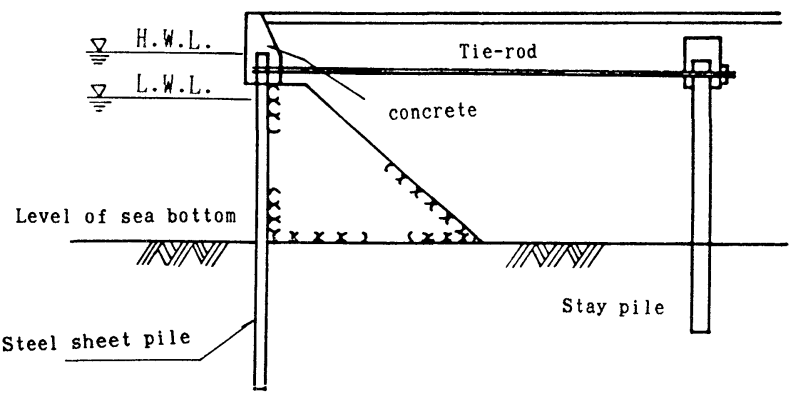

Fig. 1 Example of Steel Sheet Pile in Pier.

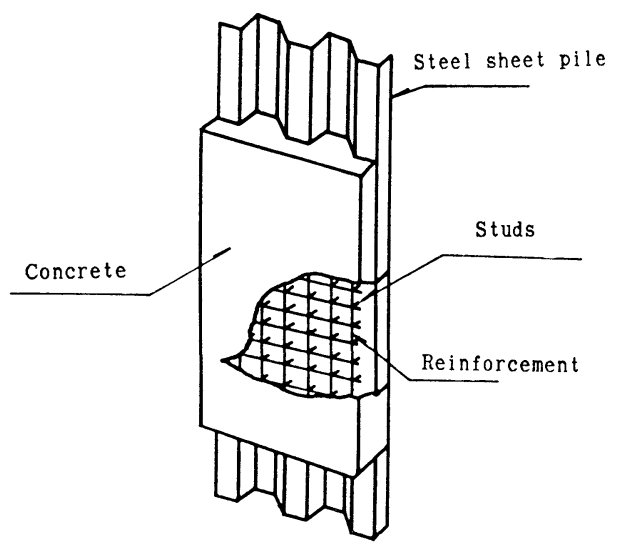

Fig. 3 Outline of the Reinforced Concrete Covering Method

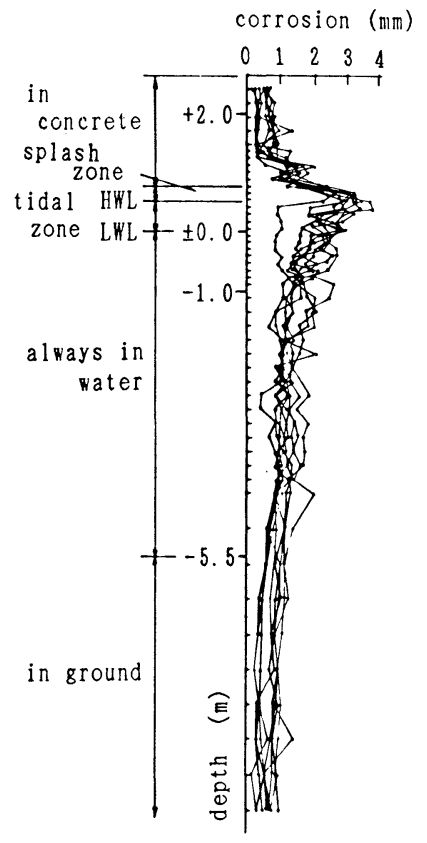

Fig. 2 Corrosion Amount of Sheet Piles.

\section{(2) Outline of repair method}

The purpose of repair work is to restore the lost strength of a steel sheet pile. When stress calculated against design external forces exceeds an allowable stress, or when calculated stress is feared to exceed an allowable stress near future, repair work should be considered. Although various methods for repair have been proposed $d^{4)}$, the reinforced concrete covering method ${ }^{5)}$ is frequently employed. The outline of this method is shown in Fig. 3. Rust and sticking organisms on a steel sheet pile are removed by surface preparation. Studs of 12 to $16 \mathrm{~mm}$ in diameter are welded by a stud gun to the steel sheet pile followed by arranging additional reinforcements in front of steel sheet piles. Concrete is cast into the form. The thickness of the covering concrete is usually about $250 \mathrm{~mm}$ and concrete cover to embedded steel bars is more than $70 \mathrm{~mm}$. The covering range is usually from the lower end of an upper slab through about the part at L. W. L. $-2.0 \mathrm{~m}$. After the repair, both steel sheet piles and the reinforced concrete resist external forces. In other words, the part where repair work has been done, can be considered as a composite member.

\section{CALCULATION METHOD ON COMPOSITE STEEL SHEET PILE}

\section{(1) Strength as composite steel sheet pile}

Induced stresses due to flexural moment can be calculated with the following method.

a) Calculation of neutral axis depth

On the assumption that strain is proportional to the distance from the neutral axis, the following formula is derived, which is schematically shown in Fig. 4. Here, the tensile strength of concrete is not taken into consideration and a steel sheet pile and the reinforced concrete are assumed to be completely composed. 


$$
\begin{aligned}
& E_{s} \varepsilon\left(x-d_{t}\right) A_{s}+E_{s} \varepsilon\left(x-d_{c}\right) A_{s}^{\prime} \\
& \quad+E_{s} \int_{x-H_{s}}^{x} b_{s y} \varepsilon(y) d y+E_{c} \int_{0}^{x-t} b_{c} \varepsilon(y) d y=0
\end{aligned}
$$

where, $E_{s}$ : modulus of elasticity of steel

$E_{c}$ : modulus of elasticity of concrete

$x$ : neutral axis depth

$d_{t}$ : distance from the compression edge

to tensile reinforcement

$d_{c}$ : distance from the compression edge to compressive reinforcement

$A_{s}:$ cross sectional area of tensile rein-

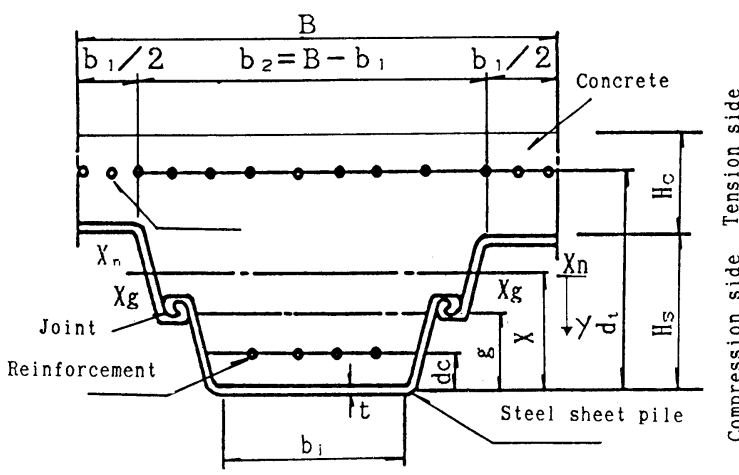

Fig. 4 Cross Section of a Covered Steel Sheet Pile.

\section{forcement}

$A_{s}^{\prime}$ : cross sectional area of compressive reinforcement

$b_{s y}$ : effective width of steel sheet pile

$b_{c}$ : width of concrete

$\varepsilon$ : strain in general

$t:$ flange thickness of steel sheet pile

$y$ : distance from the neutral axis

$H_{s}$ : height of one pair of steel sheet piles

From the distribution of strains, the following relationship is obtained.

$\frac{\varepsilon\left(x-d_{t}\right)}{x-d_{t}}=\frac{\varepsilon\left(x-d_{c}\right)}{x-d_{c}}=\frac{\varepsilon(y)}{y}$

$\frac{E_{s}}{E_{c}}=n$

The effective width of concrete in compression is obtained as follows :

$$
b_{c}(y)=b_{2}-\frac{b_{2}-b_{1}}{H_{s}}\left(H_{s}-x+y\right)=\frac{1}{H_{s}}\left[b_{1} H_{s}+\left(b_{2}-b_{1}\right) x-\left(b_{2}-b_{1}\right) y\right]
$$

where, $b_{1}$ : flange width of steel sheet pile in compression side

$b_{2}$ : flange width of steel sheet pile in tension side

$B$ : width per one pair of steel sheet piles $\left(=b_{1}+b_{2}\right)$

Now, substitute Eq. (1) into Eq. (4),

$$
\begin{aligned}
& n\left[\left(x-d_{t}\right) A_{s}+\left(x-d_{c}\right) A_{s}^{\prime}+A_{s y}(x-g)\right]+\frac{1}{H_{s}}\left[b_{1} H_{s}+\left(b_{2}-b_{1}\right) x\right] \frac{(x-t)^{2}}{2} \\
& -\frac{1}{H_{s}}\left(b_{2}-b_{1}\right) \frac{(x-t)^{3}}{3}=0
\end{aligned}
$$

where, $A_{s y}$ : cross sectional area of steel sheet pile

$$
g: \text { neutral axis depth of steel sheet piles themselves }
$$

Here, $t$ is neglected because it is considerably smaller than $x$.

$$
\frac{1}{6} \frac{b_{2}-b_{1}}{H_{s}} x^{3}+\frac{b_{1}}{2} x^{2}+n\left(A_{s}+A_{s}^{\prime}+A_{s y}\right) x-n\left(A_{s} d_{t}+A_{s}^{\prime} d_{c}+A_{s y} g\right)=0
$$

Position of neutral axis can be calculated by solving above formula.

b) Calculation of bending stiffness

Assuming $x_{0}$ as the solution obtained from Eq. ( 6$)$, bending stiffness $(S)$ of composite steel sheet pile is given by Eq. (7). Here, $t$ is neglected again.

$$
S=E_{s}\left[\left(x_{0}-d_{t}\right)^{2} A_{s}+\left(x_{0}-d_{c}\right)^{2} A_{s}^{\prime}+I_{s y}\right]+E_{c}\left(\frac{b_{2}-b_{1}}{12 H_{s}} x_{0}^{4}+\frac{b_{1}}{3} x_{0}^{3}\right) \cdots
$$

where, $I_{s y}$ : moment of inertia of steel sheet pile, taking the joint efficiency ${ }^{6) .7)}$ into consideration 
c) Calculation of stress

Stresses in respective parts where flexural moment is increased after the repair, are expressed by the following formulae.

$$
\begin{aligned}
& \sigma_{s}=E_{s} \frac{M}{S}\left(d_{t}-x_{0}\right) \ldots \ldots \ldots \ldots \ldots \ldots \\
& \sigma_{s}^{\prime}=E_{s} \frac{M}{S}\left(x_{0}-d_{c}\right) \cdots \ldots \ldots \ldots \ldots \\
& \sigma_{s y}=E_{s} \frac{M}{S}\left(H_{s}-x_{0}\right)+\frac{M_{0}}{Z_{s y}} \ldots \ldots \\
& \sigma_{s y}^{\prime}=E_{s} \frac{M}{S} x_{0}+\frac{M_{0}}{Z_{s y}^{\prime}} \ldots \ldots \ldots \ldots \ldots \\
& \sigma_{c}^{\prime}=E_{c} \frac{M}{S}\left(x_{0}-t\right)=E_{c} \frac{M}{S} x_{0}
\end{aligned}
$$

where, $M_{0}$ : flexural moment at the repair

$M$ : increase in flexural moment after the repair

$\sigma_{s}:$ tensile stress of reinforcement

$\sigma_{s}^{\prime}:$ compressive stress of reinforcement

$\sigma_{s y}:$ tensile stress of steel sheet pile

$\sigma_{s y}^{\prime}:$ compressive stress of steel sheet pile

$\sigma_{c}^{\prime}:$ stress at the compression edge of concrete

$Z_{s y}$ : sectional modulus of steel sheet pile in tension side

$Z_{s y}^{\prime}$ : sectional modulus of steel sheet pile in compression side

In addition, mechanical and chemical characteristics of steel sheet piles which were exposed to sea water for long time do not change on the basis of investigation ${ }^{8}$.

( 2 ) Number of studs ${ }^{9}$

Composition of reinforced concrete and steel sheet piles is accomplished through studs, which are arranged along the steel sheet pile with appropriate intervals as shown in Fig. 5. The necessitated number of studs is calculated by the following formula ${ }^{1)}$.

$$
\begin{aligned}
Q_{t} & =\frac{M}{n_{t} y_{t}^{2}+n_{c} y_{c}^{2}} y_{t} \leqq Q_{a} . \\
Q_{c} & =\frac{M}{n_{t} y_{t}^{2}+n_{c} y_{c}^{2}} y_{c} \leqq Q_{a} .
\end{aligned}
$$

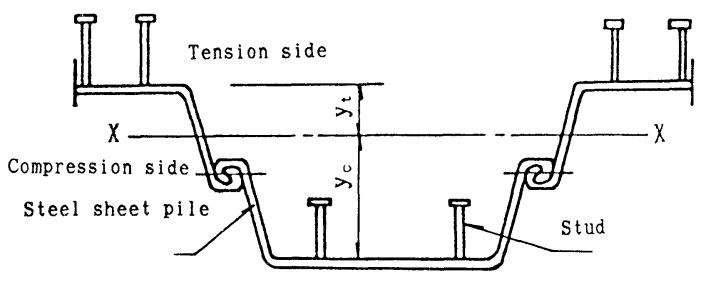

Fig. 5 Arrangement of Studs.

where, $M$ : increase in flexural moment

$Q_{a}$ : allowable shearing force

$Q_{t}, Q_{c}$ : shearing forces act on a stud in tension side and in compression side respectively

$n_{t}, n_{c}$ : number of studs in tension side and in compression side respectively

$y_{t}, y_{c}$ : distance from the neutral axis to lower ends of studs in tension side and in compression side respectively

Both calculated shear forces should be less than the allowable shear force. Pull-out forces of studs from concrete are also confirmed to be smaller than the allowable force, which will be described in 5. (3).

\section{LOADING TEST}

\section{(1) Test specimen}

Flexural loading tests on 8 test beam specimens have been undertaken. The outline of the specimens is summarized in Table 1. Their overall length and width are identical of $5.0 \mathrm{~m}$ and $1.6 \mathrm{~m}$ respectively. Fig. 6 
Table 1 List of test specimen.

\begin{tabular}{|c|c|c|c|}
\hline No. & Kind & $\begin{array}{l}\text { Initial } \\
\text { stress }\end{array}$ & Kinds of concrete \\
\hline No. 1 & $\begin{array}{l}\text { Reinforced concrete covering } \\
\text { method } \\
\text { Number of studs : }\end{array}$ & $\begin{array}{l}\text { Not } \\
\text { applied }\end{array}$ & $\begin{array}{l}\text { Ordinary Portland } \\
\text { cement }\end{array}$ \\
\hline No. 2 & $\begin{array}{l}\text { Reinforced concrete covering } \\
\text { method } \\
\text { Number of studs : }\end{array}$ & $\begin{array}{l}1800 \\
\mathrm{kgf} / \mathrm{cm}^{2}\end{array}$ & $\begin{array}{l}\text { Rapid hardening } \\
\text { cement }\end{array}$ \\
\hline No. 3 & $\begin{array}{l}\text { Reinforced concrete covering } \\
\text { method } \\
\text { Number of studs : }\end{array}$ & $\begin{array}{l}3000 \\
\mathrm{kgf} / \mathrm{cm}^{2}\end{array}$ & $\begin{array}{l}\text { Rapid hardening } \\
\text { cement }\end{array}$ \\
\hline No. 4 & $\begin{array}{l}\text { Reinforced concrete covering } \\
\text { method } \\
\text { Number of studs : } \\
\end{array}$ & $\begin{array}{l}\text { Not } \\
\text { applied }\end{array}$ & $\begin{array}{l}\text { Ordinary Portland } \\
\text { cement }\end{array}$ \\
\hline No. 5 & $\begin{array}{l}\text { Reinforced concrete covering } \\
\text { method } \\
\text { Stud connector with head: } 36 \\
\text { J type stud connector : } 36\end{array}$ & $\begin{array}{l}\text { Not } \\
\text { applied }\end{array}$ & $\begin{array}{l}\text { Ordinary Portland } \\
\text { cement }\end{array}$ \\
\hline No. 6 & $\begin{array}{lr}\text { Reinforced concrete covering } \\
\text { method } \\
\text { Headed studs : } \\
\text { Stirrups : } & 72 \\
\end{array}$ & $\begin{array}{l}\text { Not } \\
\text { applied }\end{array}$ & $\begin{array}{l}\text { Ordinary Portland } \\
\text { cement }\end{array}$ \\
\hline No. 7 & Steel sheet pile only & $\begin{array}{l}\text { Not } \\
\text { applied }\end{array}$ & \\
\hline No. 8 & Reinforced concrete only & $\begin{array}{l}\text { Not } \\
\text { applied }\end{array}$ & $\begin{array}{l}\text { Rapid hardening } \\
\text { cement }\end{array}$ \\
\hline
\end{tabular}

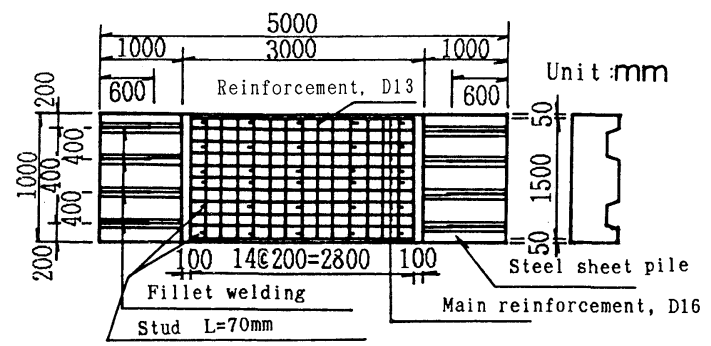

Fig. 6 Structure of Test Beam.
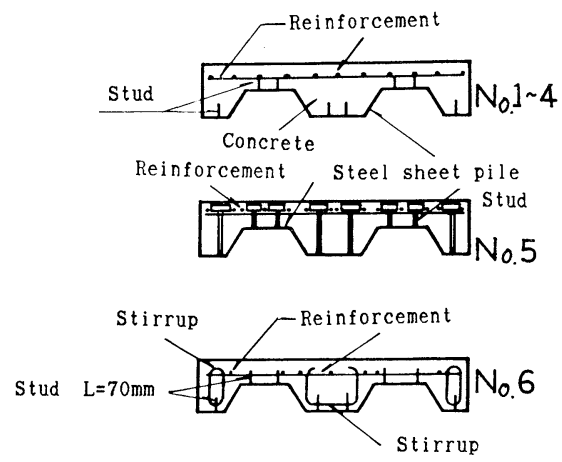

Fig. 8 Arrangement of Shear Connectors.

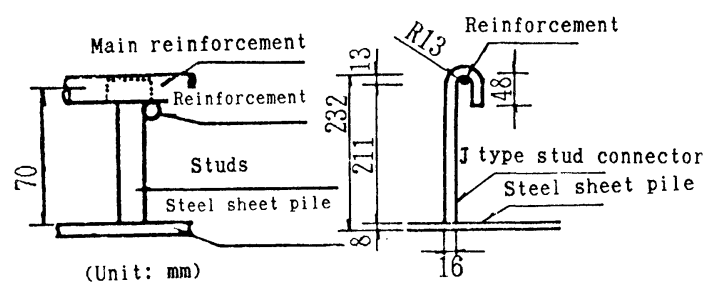

Fig. 7 Structure of Shear Connectors.
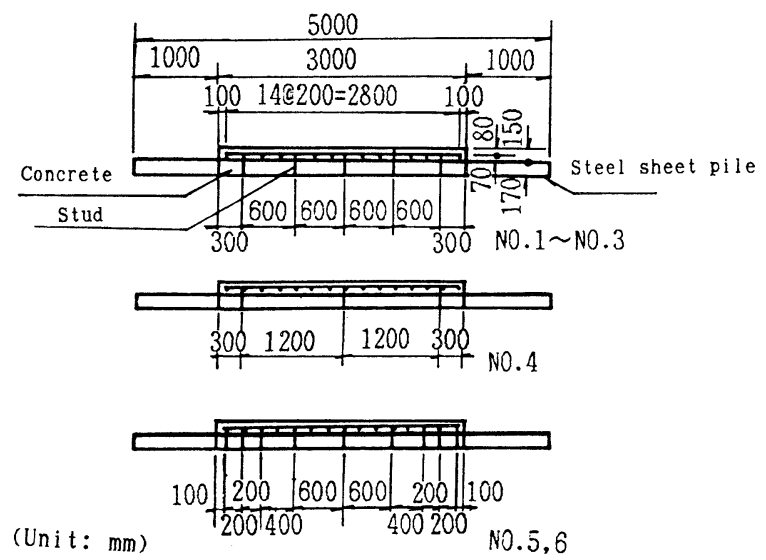

Fig. 9 Arrangement of Studs in Axial Direction.

shows the details of No. 1 beam. Four steel sheet piles of SP-IA, Grade SY 30 are assembled to fabricate one beam. Central part of $3.0 \mathrm{~m}$ is covered by reinforced concrete. Deformed reinforcing bars of $16 \mathrm{~mm}$ in diameter and Grade SD-30 A are arranged longitudinally at intervals of $150 \mathrm{~mm}$. In addition, those of $13 \mathrm{~mm}$ in diameter and Grade SD-30 A are arranged transversely at intervals of $150 \mathrm{~mm}$. Shear connectors of headed studs and stirrups are installed for composing the reinforced concrete and the steel sheet piles. In Nos. 1 through 4 beams, headed studs of $16 \mathrm{~mm}$ in diameter and $75 \mathrm{~mm}$ in length are welded to the steel 
Table 2 Mix Proportion of Concrete.

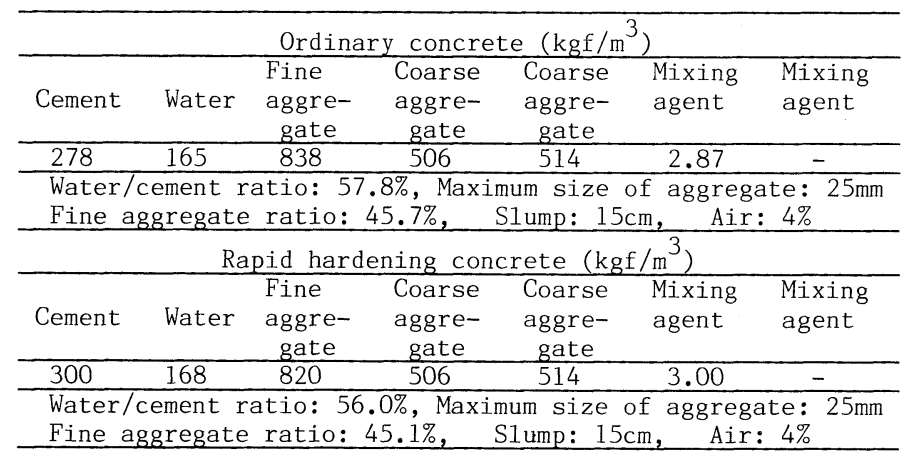

Table 3 Strength of Concrete.

\begin{tabular}{ccccc}
\hline No. & $\begin{array}{c}\text { Compressive } \\
\text { strength } \\
\left(\mathrm{kgf} / \mathrm{cm}^{2}\right)\end{array}$ & $\begin{array}{c}\text { Tensile } \\
\text { strength } \\
\left(\mathrm{kgf} / \mathrm{cm}^{2}\right)\end{array}$ & $\begin{array}{c}\text { Young's } \\
\text { modulus } \\
\left(\mathrm{kgf} / \mathrm{cm}^{2}\right)\end{array}$ & $\begin{array}{c}\text { Poisson's } \\
\text { ratio }\end{array}$ \\
\hline No.1 & 215 & 21.2 & $2.06 \times 10^{5}$ & 0.16 \\
\hline No.2 & 224 & 22.8 & $2.40 \times 10^{5}$ & 0.18 \\
\hline No.3 & 311 & 22.4 & $2.85 \times 10^{5}$ & 0.20 \\
\hline No.4 & 215 & 19.0 & $2.26 \times 10^{5}$ & 0.17 \\
\hline Nos.5,6 & 308 & 18.0 & $2.31 \times 10^{5}$ & 0.21 \\
\hline No.8 & 233 & 22.1 & $2.69 \times 10^{5}$ & 0.23 \\
\hline$*$
\end{tabular}

*) No.2 and No.3 are rapid hardening cement

Table 4 Strength of Steel.

\begin{tabular}{|c|c|c|c|c|c|}
\hline Material & Grade & $\begin{array}{c}\text { Yield } \\
\text { strength } \\
\left(\mathrm{kgf} / \mathrm{cm}^{2}\right)\end{array}$ & $\begin{array}{l}\text { Tensile } \\
\text { strength } \\
\left(\mathrm{kgf} / \mathrm{cm}^{2}\right)\end{array}$ & $\begin{array}{l}\text { Elastic } \\
\text { modulus } \\
\left(\mathrm{kgf} / \mathrm{cm}^{2}\right)\end{array}$ & $\begin{array}{c}\text { Elongation } \\
(\%)\end{array}$ \\
\hline Steel sheet & JIS A & & & & \\
\hline $\begin{array}{l}\text { pile } \\
\text { SP - 1A }\end{array}$ & $\begin{array}{l}5528 \\
\text { SY30 }\end{array}$ & 4600 & 5900 & $2.03 \times 10^{6}$ & 21.5 \\
\hline $\begin{array}{l}\text { Reinforce- } \\
\text { ment } \\
\text { D13 }\end{array}$ & $\begin{array}{l}\text { JIS G } \\
3112 \\
\text { SD30 }\end{array}$ & 3666 & 5390 & - & 24.2 \\
\hline $\begin{array}{l}\text { Reinforce- } \\
\text { ment } \\
\text { D16 }\end{array}$ & $\begin{array}{l}\text { JIS G } \\
3112 \\
\text { SD30 }\end{array}$ & 3800 & 5500 & - & 28.0 \\
\hline $\begin{array}{l}\text { Stud } \\
\text { M16 }\end{array}$ & $\begin{array}{l}\text { JIS B } \\
1197 \\
\text { SWCH }\end{array}$ & - & 4280 & - & 26.0 \\
\hline
\end{tabular}

sheet piles. In No. 5 beam, J-shaped reinforcement approximately $230 \mathrm{~mm}$ in length, and in No. 6 beam, stirrups in $13 \mathrm{~mm}$ diameter are used. Fig. 7 shows the details of the shear connectors. The arrangement of the shear connectors are shown in Figs. 8 and 9. The studs are arranged on the flange of the steel sheet piles in 2 lines at intervals of $600 \mathrm{~mm}$ for Nos. 1 through 3 beam and in 1 line at intervals of $1200 \mathrm{~mm}$ for No. 4 beam. The number of studs is decided to resist shear forces by Eqs. (13) and (14). In test specimens of No. 5 and No.6, shear connectors are arranged densely at the end of reinforced concrete.

In Nos. 2 and 3 beams, initial stresses of $1800 \mathrm{kgf} / \mathrm{cm}^{2}$ and $3000 \mathrm{kgf} / \mathrm{cm}^{2}$ are introduced respectively to the steel sheet pile before concrete casting. The initial stress simulates actual conditions; that is, fairly large stress is already induced in steel sheet piles at their thin parts due to earth and water pressures before repair work. The beams are strengthened by steel plates at the loading points and the supports to prevent from widening and twisting. The beams of steel sheet piles only (No. 7) and reinforced concrete only (No.8) are also fabricated to confirm the effectiveness of the concrete covering. 


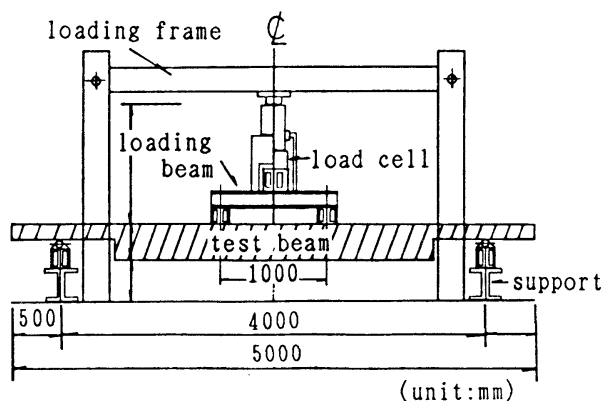

Fig. 10 Test Set-up for the Beams.
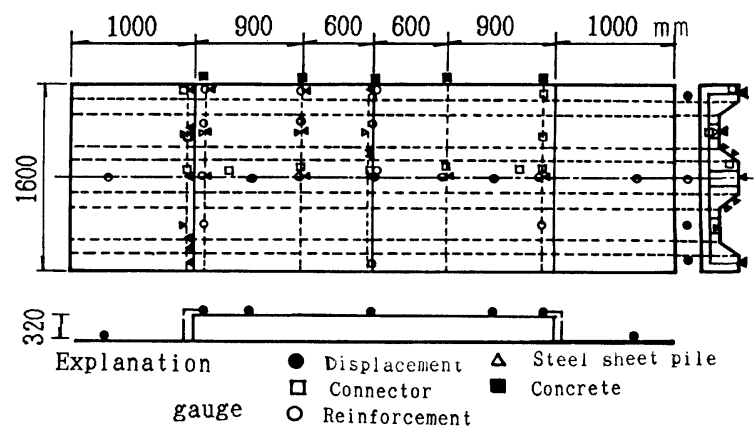

Fig. 11 Positions of Measurement.

\section{(2) Used materials}

Cements used for the concrete are either ordinary Portland cement or rapid hardening cement. Mix proportions of the concrete are presented in Table 2. Design strength of the concrete is $240 \mathrm{kgf} / \mathrm{cm}^{2}$ and its slump is about $150 \mathrm{~mm}$. Table 3 presents the compressive strength of the concrete at the loading tests. The mechanical characteristics of the steel are summarized in Table 4.

( 3 ) Loading

Fig. 10 shows the test set-up. Load is applied from the steel sheet pile side symmetrically at two points. The distances between the supports and between the loading points are $4.0 \mathrm{~m}$ and $1.0 \mathrm{~m}$ respectively. An manually operated hydraulic jack is used for applying the load which is increased monotonously. Loading is quitted when distinct failure appears.

\section{(4) Instrumentation}

Measurements are made during the test as follows : applied loads by a load cell ; deflection of the beam by displacement transducers; slip and separation by displacement transducers; strains of the steel sheet pile, reinforcing bars, and concrete by strain gauges ; width of crack by contact-type gauges ; propagation of cracks by visual inspection.

The arrangement of measuring instruments slightly differs among the test beams. Fig. 11, for example, shows the arrangement in No. 1 beam.

\section{RESULTS OF TEST AND DISCUSSION}

\section{(1) Development of cracks and mode of failure}

Formation of cracks in Nos. 1, 5, and 6 beams are shown in Figs. 12, 13, and 14 respectively. In No. 1 beam, cracks were initiated at the central parts when the load was 4 tf and then numbers of cracks increased. When the load reached $16 \mathrm{tf}$, cracks occurred horizontally at the end of the concrete. These cracks were caused by shear and tensile collapse of concrete around studs. When the load reached $32 \mathrm{tf}$,

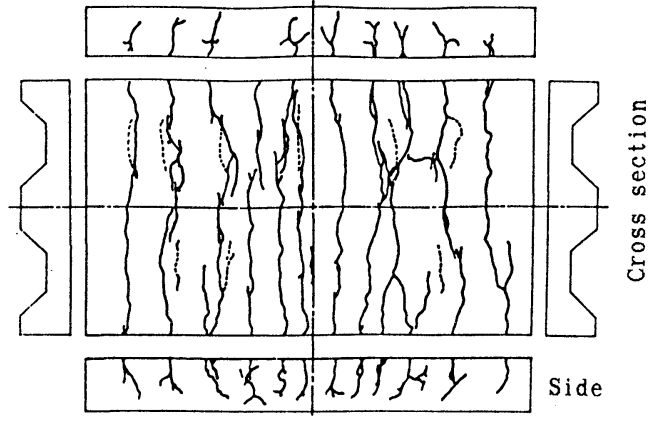

Fig. 12 Crack Formation in No. 1 Beam.

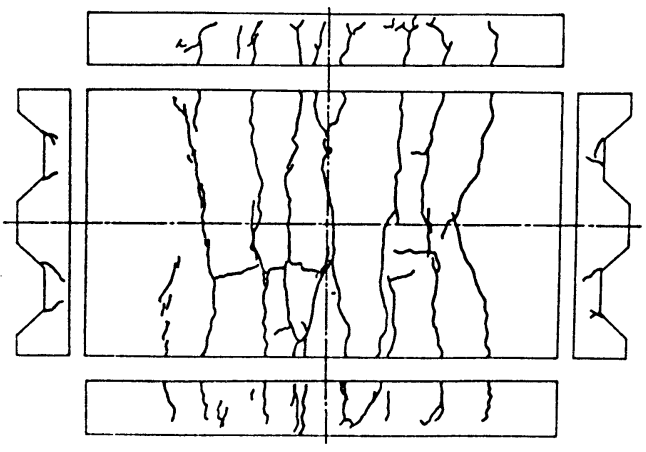

Fig. 13 Crack Formation in No. 5 Beam 


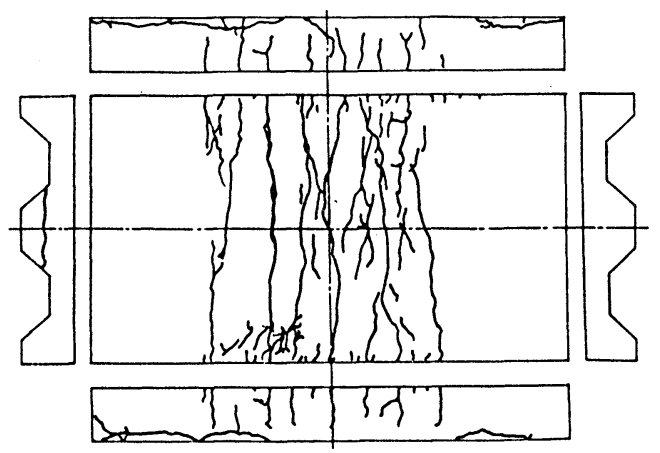

Fig. 14 Crack Formation in No. 6 Beam.
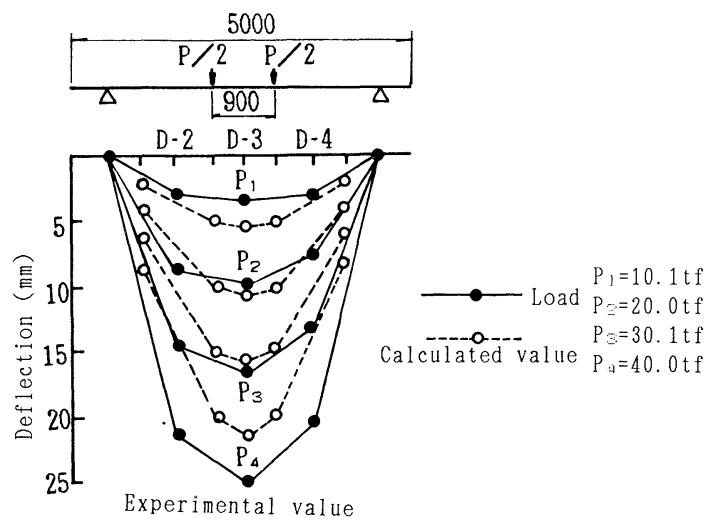

Fig. 16 Distribution of Deflection (No. 4 beam).

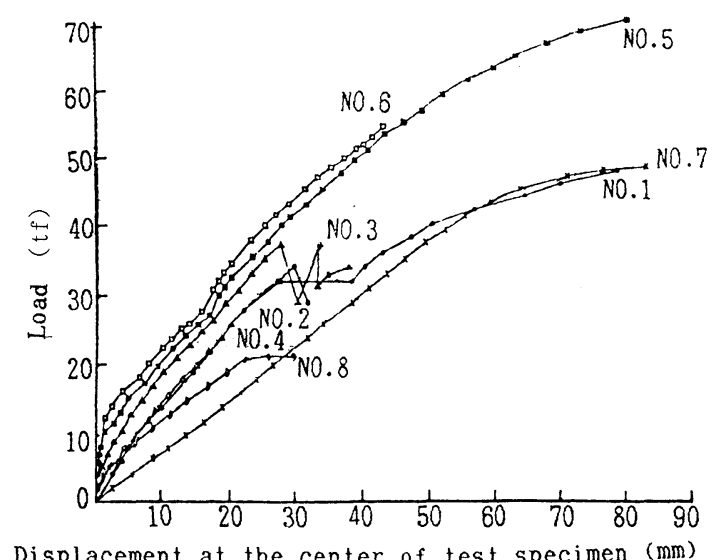

Displacement at the center of test specimen $(\mathrm{mm})$

Fig. 15 Relationship between Load and Midspan Deflection.

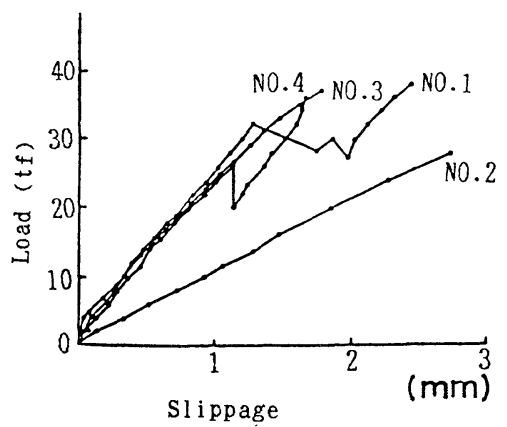

Fig. 17 Relative Displacement at the End of Reinforced Concrete.

concrete was crushed in conical shape around studs, and the steel sheet pile and the reinforced concrete separated at its end. Failure of the test beam subsequently progressed and buckling at the compression edge of the steel sheet pile was finally observed.

The process of failure of Nos. 2 through 4 beams showed almost similar to that of No. 1 beam. In No. 5 beam, initial cracks occurred at the load of 9.2 tf followed by developing flexural cracks. Finally, crushing of concrete between the loading points was observed. However, the failure at the end of the concrete, like of No. 1 beam, was not observed. The ultimate load of No. 5 beam was the largest among the test beams. In No. 6 beam, flexural cracks developed like the other test beams, but in final stage, shear failure of concrete was observed near the stirrups.

After the loading tests, tensile fracture of the embedded steel was investigated, which made clear that the studs and the reinforcing bars did not collapse.

\section{( 2 ) Relationship between load and displacement}

The relationship between load and deflection at the midspan of the test beams is shown in Fig. 15. The calculated maximum flexural moment of the test beams by Eq. ( 7 ) is $12.2 \mathrm{tf} \cdot \mathrm{m}$, which is $31.3 \mathrm{tf}$ in terms of the load. Here, the allowable stress of the steel is $2700 \mathrm{kgf} / \mathrm{cm}^{2}$, which is the value of 1.5 times the ordinary allowable one. It can be said that Nos. 1 through 6 beams had higher yield strengths than the designed value anyhow. Nos. 1 through 4 beams, however, did not have sufficient surplus strengths and rigidities because of destruction caused by pull-out shear of concrete at the end of reinforced concrete. Therefore, their mechanical properties were not good. Long studs or stirrups should be necessary. Initial stiffnesses of the test beams where initial stress was introduced showed no remarkable difference compared to that without initial stress (No. 1 beam), but their ultimate loads were slightly smaller than that of No. 1 beam. 


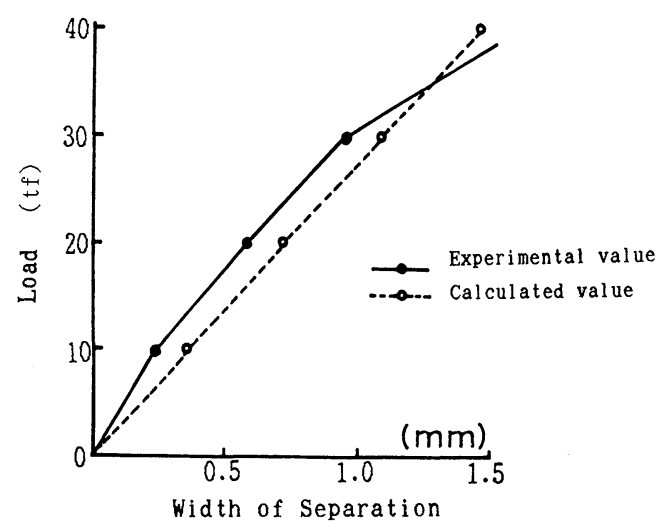

Fig. 18 Separation of the Steel Sheet Pile and Concrete.
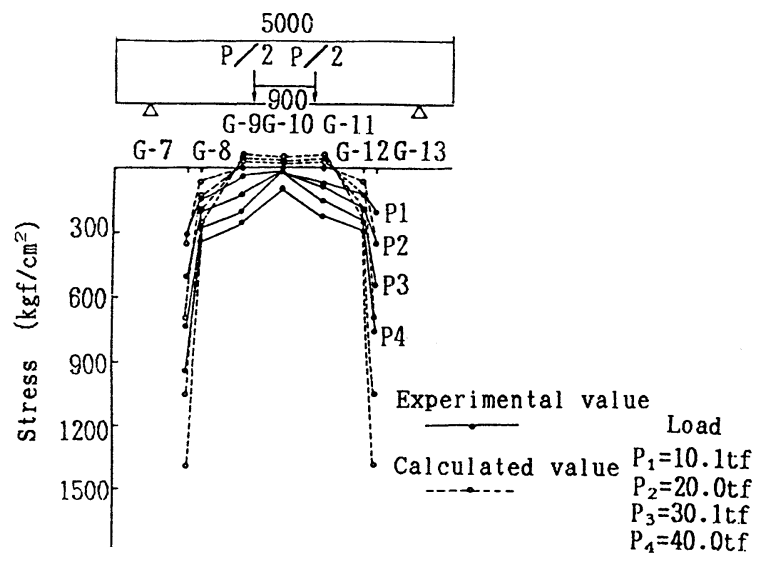

Fig. 20 Stress of Studs
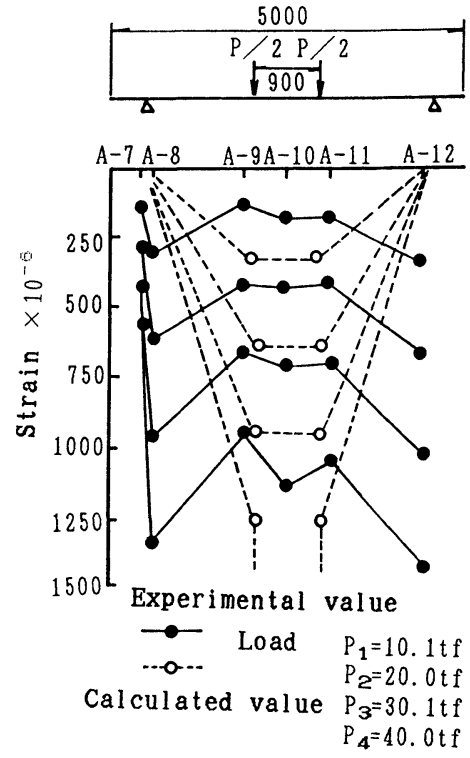

Fig. 19 Distribution of Strain.

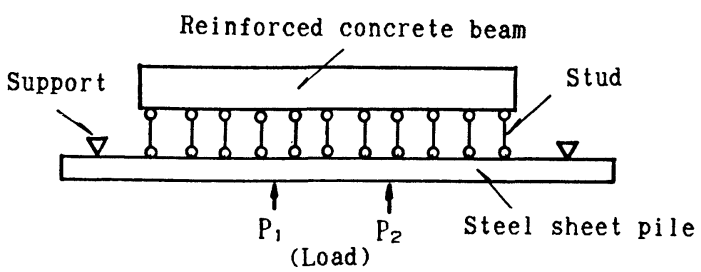

Fig. 21 Calculation Model for Pull-out Forces of Studs.

The distributions of deflection of No. 4 beam at the loads of 10, 20, 30, and $40 \mathrm{tf}$ are shown in Fig. 16 . While the load was small, the distribution of the deflection bent at D- 2 and D- 3 in the figure where the sectional modulus changed. With increase in the load, the concrete covered part showed large deflection because of the occurrence of cracks. The calculated values of deflection obtained as a complete composite beam are also shown in the figure. In this calculation, the joint efficiency ${ }^{6) .7)}$ of U-type sheet piles is determined to be 0.83 . This value is obtained from the loading test on No. 7 beam. The experimental value and the calculated value showed fairly good agreement until the steel yielded.

Fig. 17 shows relative displacement (slip) between the steel sheet piles and the concrete at its end. The relative displacement was about $1 \mathrm{~mm}$ at the load of $30 \mathrm{tf}$. Fig. 18 shows the width of separation at the same position. Separation began when the load was small, and its width reached as large as $1.0 \mathrm{~mm}$ at the load of $30 \mathrm{tf}$. The slip is related to the degree of composition, and the separation is both the degree of composition and the durability of materials.

( 3 ) Distribution of strain

Fig. 19 shows the longitudinal strain distribution of the steel sheet piles at its compression edge of No. 4 beam. Remarkably large strains occurred near the studs at the end of the concrete. Axial stress of the studs in No. 4 beam is shown in Fig. 20. These values are obtained by a pair of strain gauges attached to studs. Axial stress was dominant in the studs. As shown in this figure, large pull-out forces occurred at the end of the concrete.

Thus, the strength and the durability of the composite beam are greatly affected by the separation at the end or the pull-out of the studs from the concrete. To take the results into consideration for designs, a 
calculation model shown in Fig. 21 is proposed here which can estimate the separation and the pull-out force. In the model, the concrete and the steel sheet pile are replaced to beams and the studs are replaced to springs. The separation should be calculated taking account of elongation of studs and bond behaviours of surrounding concrete. Here, the separation is defined as the elongation of studs themselves, which will provide the conservative solution.

Figs. 18 and 20 show the comparison between the experimental results and the calculated ones on the separation and the pull-out force. From the comparison, the experimental results and the calculated results showed good agreement. Therefore, the simple calculation model in Fig. 21 can apply to estimate the separation and the pull-out forces of studs, while cracking, the correlation of pull-out and shear forces, and so on occur in actual beams.

\section{CONCLUSIONS}

The following main conclusions are obtained from the present research.

(1) To compose reinforced concrete partially on steel sheet piles, it is necessary to provide sufficient reinforcement at the end of the reinforced concrete coverage. If shear connectors are not fixed tightly on tensile reinforcement, concrete around the shear connectors is collapsed and the stiffness of the composite beam shows rapid deterioration by pull-out tensile forces at the end of the concrete coverage. When long studs or stirrups are used, such phenomena are not observed. Therefore, strength and rigidity of the test specimens are not against expectation, hence composing of steel sheet piles and reinforced concrete is insured.

(2) As considerable stress concentration on studs was observed at the end of reinforced concrete coverage, it is necessary to give consideration on both shear and pull-out of studs there. It is also necessary to arrange more studs than at the other parts, or to use longer shear connectors.

(3) The slip of steel sheet piles and reinforced concrete at its end is not so much but separation is found at the relatively small load stage. Careful attention is required because there is a danger of corrosion caused by penetration of sea water. The values of separation and pull-out forces of studs are approximately calculated by the simple calculation model proposed in this paper.

(4) When initial stress is introduced into steel sheet piles before composing, the yield strength and initial stiffness are almost similar to those without initial stress until the yield of tension reinforcement.

(5) By the calculation formula of bending yield strength of composite beams shown in this paper, calculated yield strength of the test specimen was larger than the experimental values. However, as described in Conclusion (1), it is impossible to maintain sufficient toughness or deformation capacity without careful attention on structural details of shear connectors, and so on.

(6) For the calculation of bending stiffness of composite beams, it is necessary to take the joint efficiency (rate of stiffness decrease caused by slipping at joint) of U-type steel sheet piles into consideration. The joint efficiency of the test specimens in this study was about 0.8 , but in practical design, the value shall be determined considering ground condition and installation condition of a structure.

\section{REFERENCES}

1) Coastal Development Institute of Technology : Manual for Repair of Steel Structures in Port and Harbours, Tokyo, March 1986 (in Japanese).

2) Kiyomiya, O., Noguchi, T. and Yokota, H. : Mechanical Properties of Repaired Steel Sheet Piles, Report of the Port and Harbour Research Institute, Vol.28, No. 3, pp. 147-198, March 1990 (in Japanese).

3) Zen, K. : Studies on the Situation of Corrosion of Steel Structures in Marine Environments and Measures against Concentrated Corrosion, Report of the Port and Harbour Research Institute, Vol. 15, No. 3, pp. 163-177, September 1976 (in Japanese) .

4) Ishiwata, T. et al. : Estimation System of Corrosion of Port Facilities, Technical Note of the Port and Harbour Research Institute, No. 501, pp. 27-30, December 1984 (in Japanese).

5) Kiyomiya, O., Chiba, T. and Yokoi, T. : Mechanical Properties of Repaired Steel Pipe Pile Covered by Reinforced Concrete, 
Report of the Port and Harbour Research Institute, Vol.27, No. 1, pp. 125-173, March 1988 (in Japanese).

6) Shiraishi, M. : Theoretical Analysis of U-Type Sheet Pile Wall on Shearing Resistance Force of Interlocking Joints and Sectional Properties, Proceedings of JSCE, No. 385/IV-7, pp. 49-58, September 1987 (in Japanese).

7) Konoike, K. : Experimental Study on Sectional Rigidity of Steel Sheet-Pile Wall, Proceedings of JSCE, No. 373/IV-5, pp. 74-83, September 1986 (in Japanese).

8) Kiyomiya, O., Chiba, T., Yokota, H. and Abe, M. : Corrosion Survey and Residual Strength of Steel Pipe Piles for Pier, Technical Note of the Port and Harbour Research Institute, No.593, 29 p., September 1987 (in Japanese).

9) Stud Association: Stud Welding, p. 122, 1982 (in Japanese). 